\title{
PERTANIAN
}

\section{IDENTIFIKASI KARAKTERISTIK MORFOLOGI DAN MOLEKULER 21 VARIETAS PADI AROMATIK (Oryza sativa L.) BERDASARKAN PENANDA RAPD (Random Amplified Polymorphic DNA)}

\author{
Identification of Mophological Characteristics and Molecular of 21 Varieties Aromatic Rice \\ (Oryza sativa L.) Based on RAPD Marker (Random Amplified Polymorphic DNA)
}

\section{Irza Guari Syah Fitri dan Tri Handoyo*}

\author{
Program Studi Agroteknologi, Fakultas Pertanian, Universitas Jember \\ Jalan Kalimantan 37, Kampus Tegal Boto Jember 68121 \\ *E-mail: trihandoyo1971@,gmail.com
}

\begin{abstract}
Aromatic rice (Oryza sativa L.) is one type of rice that has aroma and high selling price than non-aromatic rice. The variety development is needed to form superior aromatic rice. The variety development requires information about kinship and diversity between varieties. Kinship analysis with identification of morphological characteristics is an observation based on taxonomic approach. This research aims to determine the morphological characteristics and kinship of 21 aromatic rice varieties. The research was conducted from March to September 2018 with a randomized block design (RBD) of 3 replications. Observation variables used plant height $(\mathrm{cm})$, number of productive tillers (tiller), age of flowering and harvesting (days), weight of 100 grain (gram), shape of grain, color of grain, color of rice and DNA band pattern as molecular data. Morphological data were analyzed by variance (ANOVA) and cluster analysis with UPGMA program (Unweight Pair Group Method with Arithmetic Mean) using DIST Coefficient on NTSYS 2.02 software. Molecular data showed in visualisation of DNA band using Primer OPB-07 based on RAPD marker. The research results showed the differences in morphological characters and kinship levels. Cluster analysis forms 2 clusters and 2 sub-clusters.
\end{abstract}

Keywords: Aromatic Rice, Mophological Diversity, RAPD, Dendrogram

\begin{abstract}
ABSTRAK
Padi aromatik (Oryza sativa L.) merupakan salah satu jenis padi yang memiliki aroma wangi dan memiliki harga jual yang lebih tinggi dibanding padi biasa. Pengembangan varietas diperlukan untuk membentuk padi aromatik yang lebih unggul. Pengembangan varietas membutuhkan informasi tentang kekerabatan dan keanekaragaman antar varietas. Analisis kekerabatan dengan identifikasi karakteristik morfologi merupakan suatu observasi berdasarkan pendekatan taksonomi. Percobaan ini bertujuan untuk mengetahui karakteristik morfologi dan molekuler 21 varietas padi aromatik. Percobaan dilakukan di mulai Maret - September 2018 dengan Rancangan Acak Kelompok (RAK) 3 ulangan. Variabel pengamatan menggunakan tinggi tanaman (cm), jumlah anakan produktif (batang), umur berbunga dan panen (HSS), bobot 100 gabah, bentuk gabah, warna gabah, dan warna beras serta pola pita DNA sebagai data molekuler. Data morfologi dianalisis dengan ragam (ANOVA) serta dianalisis gerombol dengan program UPGMA (Unweight Pair Group Method with Arithmetic Mean) menggunakan DIST Koefisien pada software NTSYS 2.02. Data molekuler ditunjukkan dalam bentuk visualisasi DNA menggunakan primer OPB-07 berdasarkan penanda RAPD. Hasil percobaan menunjukkan perbedaan karakter morfologi dan tingkat kekerabatan yang berbeda. Analisis gerombol membentuk 2 cluster dan 2 sub-cluster.
\end{abstract}

Kata kunci: Padi Aromatik, Kekerabatan Morfologi, RAPD, Dendrogram

How to citate: Fitri, I. G. S dan T. Handoyo. 2019. Identifikasi Karakteristik Morfologi dan Molekuler 21 Varietas Padi Aromatik (Oryza sativa L. ) Berdasarkan Penanda RAPD (Random Amplified Polymorphic DNA). Berkala Ilmiah Pertanian, 2 (2): $72-76$.

\section{PENDAHULUAN}

Padi aromatik merupakan salah satu jenis padi yang memiliki aroma wangi. Aroma wangi ini diperoleh dari kandungan senyawa 2,acetyl-1-pyrrolin. Padi aromatik juga memiliki keunggulan lain yaitu harga jual yang tinggi yaitu mencapai 22,5 kali dibandingkan beras biasa (Haryanto, 2005). Padi aromatik juga berkontribusi dalam pasar padi internasional sebanyak 15-18\% (Giraud, 2013). Berdasarkan hal tersebut padi aromatik lebih digemari oleh masyarakat dan produsen. Berdasarkan data Badan Pusat Statistika, produksi padi pada tahun 2017 mencapai 75 juta ton per tahun. Nilai ini diprediksi akan terus meningkat mengingat ketersediaan beras yang sangat tinggi berkaitan dengan peningkatan jumlah penduduk setiap tahunnya.

Permintaan beras aromatik di pasar internasional meningkat dalam 15 tahun terakhir. Negara-negara produsen beras berusaha untuk meningkatkan kualitas beras aromatik. Adanya permintaan produksi yang tinggi, padi aromatik dituntut untuk menghasilkan padi yang lebih unggul. Pengembangan varietas sangat diperlukan untuk membentuk kualitas padi yang lebih unggul (Elsera et al 2015; Napasintuwong, 2012). 
Menurut Wahid dan Nurdin (2013), untuk mengembangkan varietas diperlukan informasi tentang keanekaragaman varietas. Informasi keanekaragaman dan hubungan kekerabatan sangat diperlukan dalam merakit varietas unggul. Kekerabatan antar tetua yang semakin jauh memungkinkan adanya peluang untuk menghasilkan kultivar baru dengan variabilitas genetik luas akan menjadi semakin besar, sebaliknya persilangan antar tetua yang berkerabat dekat akan mengakibatkan terjadinya variabilitas genetik yang sempit (Tenda et al, 2009; Rochambeau et al, 2000), sehingga perlu dilakukan analisis kekerabatan untuk mengetahui keanekaragaman genetik berbagai varietas padi yang ada. Analisis kekerabatan menggambarkan perbedaan genetik diantara individu dalam suatu organisme atau spesies. Analisis kekerabatan dapat menggunakan identifikasi karakter morfologi, fisiologis dan molekuler.

Identifikasi morfologi merupakan pengamatan berdasarkan pendekatan tanam berdasarkan taksonominya sehingga dapat mengetahui sifat-sifat tanaman tersebut. Identifikasi karakter morfologi merupakan metode yang mudah dan cepat, bisa digunakan secara langsung pada populasi tanaman kemudian data yang diperoleh dapat dijadikan sebagai deskripsi tanaman dan perbaikan sifat tanaman maupun rencana pengembangan tanaman (Saidah, dkk., 2015). Seleksi varietas padi berdasarkan karakter morfologi juga kurang terpercaya mengingat karakter utama yang diinginkan biasanya penurunan sifatnya rendah secara genetik (Becerra et al, 2015).

Identifikasi molekuler dapat memberikan hasil yang lebih presisi karena tidak dipengaruhi lingkungan. Identifikasi molekuler memanfaatkan marka molekuler sebagai pendekatan yang efisien untuk analisis keragaman genetik dan dapat dimanfaatkan secara luas diberbagai studi biologi (Nugroho, dkk., 2017). Identifikasi molekuler dapat dilakukan menggunakan penanda RAPD (Random Amplified Polymorphic DNA). Metode RAPD dilakukan berdasarkan sekuens DNA yang homolog dengan sekuens primer oligonukleotida tunggal pendek (10-12 basa).

Analisis kekerabatan dilakukan untuk mengetahui sifat-sifat morfologi yang menjelaskan kaenekaragaman 21 varietas padi aromatik serta membandingkan dengan sifat genetik berdasarkan penanda RAPD. Penelitian ini dilakukan untuk menganalisis kekerabatan padi aromatik (Oryza sativa L.) dengan identifikasi morfologi dan molekuler yang digunakan untuk mengetahui tingkat kekerabatan antar varietas padi aromatik dimana selanjutnya digunakan untuk memperbaiki varietas tersebut dengan tujuan meningkatkan produktivitas, meningkatakan cita rasa beras aromatik, dan kualitas yang tinggi guna memenuhi kebutuhan konsumen.

\section{BAHAN DAN METODE}

Penelitian ini dilaksanakan pada bulan Maret-September 2018 bertempat di Kelurahan Antirogo dan Laboratorium CDAST (Centre for Development of Advance Science and Technology), Kecamatan Sumbersari, Kabupaten Jember. Alat yang digunakan adalah cangkul, sabit, meteran, timbangan, alat semprot, papan label perlakuan, kamera dan peralatan tulis serta alat untuk percobaan lainnya. Bahan yang digunakan adalah benih padi varietas Rojolele Delanggu, Mentik Wangi Banjarsari, Pare Pulu Mandoti, Situ Bagendit, Randah Putiah, Mentik Susu Karanganyar, Sintanur, Celebes, Gilirang, Pendok, Mentik Wangi, Pandan Wangi, Kuriak Kusut, Inpari 7, Inpari 23, Batang Gadis, Umbuk Wangi, Genjah Arum, dan Gogo Fatuk Masin, insektisida, pupuk Urea $(\mathrm{N})$ dan Phonska (N:P:K) serta bahan untuk percobaan lainnya.

Penelitian disusun dengan menggunakan Rancangan Acak Kelompok non faktorial dan diulang sebanyak 3 ulangan. Data yang diperoleh selanjutnya dianalisis menggunakan analisis ragam (ANOVA). Apabila antar perlakuan berbeda nyata, maka dilanjutkan dengan uji beda nyata BNT (Beda Nyata Terkecil) dengan taraf $5 \%$. Data ini kemudian lalu diskor berupa data multistate yang jumlahnya bervariasi antar karakter. Data ini distandarisasi dengan program STAND dalam program NTSYS-pc yang merupakan nilai observasi setiap karakter dikurangi nilai ratarata katakter tersebut dibagi standar deviasi. Data yang diperoleh lalu dianalisis dengan fungsi SIMMINT (Similarity for Interval Data) berdasarkan koefisien DIST (jarak taksonomi, yang selanjutnya disebut koefisien jarak) dalam program NTSYS-pc 2.0.

\section{Prosedur Pelaksanaan Identifikasi Morfologi}

1. Persemaian: Benih padi masing-masing varietas disemai pada pot tray hingga umur $<21$ HSS sampai siap pindah tanam pada lahan.

2. Penanaman: Penanaman padi menggunakan 3 bibit padi setiap lubang dengan jarak tanam $20 \times 20 \mathrm{~cm}$ pada petak dengan populasi 25 tanaman

3. Pemupukan: Pemupukan dasar dilakukan pada saat pengolahan lahan yaitu dengan menambahkan 2 ton/Ha bahan organik. Pemupukan Phonska (N-P-K) diberikan pada umur 0-14 HST (hari setelah tanam) dengan dosis $200-250 \mathrm{~kg} / \mathrm{Ha}$. Pemupukan N (Urea) kedua dilakukan pada umur 24-28 HST dengan dosis $150 \mathrm{~kg} / \mathrm{Ha}$, dan pemupukan $\mathrm{N}$ (Urea) ketiga dilakukan pada umur 38-42 HST dengan dosis $125 \mathrm{~kg} / \mathrm{Ha}$.

\section{Pemeliharaan:}

\section{A. Penyiangan}

Penyiangan dilakukan dengan cara mekanis ataupun dengan alat yaitu membersihkan gulma yang terdapat pada lahan, dilakukan berumur 21 hari setelah tanam dan dilakukan ulang berumur 40 hari setelah tanam.

B. Pengairan

Pengairan dilakukan dengan kebutuhan tanaman dengan mengatur ketinggian genangan pada lahan sawah yang ditanami. Pada fase generatif 7-8 hari dilakukan pengairan karena akar dan anakan mulai muncul. Pengurangan genangan air dapat dilakukan setelah fase pengisian gabah pada lahan dan saat memasuki fase pemanenan lahan dikeringkan secara bertahap.

C. Pengendalian hama dan penyakit

Pengendalian hama dan penyakit dilakukan sesuai pengendalian hama terpadu. Serangan hama dan penyakit melebihi ambang ekonomi maka dilakukan penyemprotan dengan insektisida dan fungisida.

5. Pemanenan: Pemanenan dilakukan dengan ciri tanaman padi mulai menguning dan ditandai dengan tanaman mulai menguning, serta ditandai dengan masak fisiologis bulir padi berubah warna kekuningan 90-95\%, secara merata, malai mulai merunduk, dan bulir sudah berisi jika digigit akan terasa keras, dapat pula ditandai dengan umur tanaman padi yang berbeda masa panennya. Panen dilakukan dengan cara memotong jerami sekitar 20-25 cm diatas permukaan tanah.

\section{Prosedur Penelitian (Identifikasi Molekuler) \\ 1. Pengambilan Sampel dan Isolasi DNA}

DNA diisolasi dari daun muda sampel tanaman padi. Daun muda digerus dengan Nitrogen Cair $\left(\mathrm{N}_{2}\right)$. Menambahkan Buffer Ekstraksi, SDS $20 \%$, dan $\beta$-mercapto. Inkubasi $65^{\circ} \mathrm{C}$ selama 10 menit. Sentrifugasi $12.000 \mathrm{rpm}$ selama 10 menit pada $4^{\circ} \mathrm{C}$, mengambil supernatan kemudian menambahkan Isopropanol dan inkubasi $-20^{\circ} \mathrm{C}$ selama 60 menit. Sentrifugasi $12.000 \mathrm{rpm}$ selama 10 menit pada $4^{\circ} \mathrm{C}$, membuang supernatan dan menambahkan buffer TE dan PCI. Sentrifugasi $12.000 \mathrm{rpm}$ selama 10 menit pada suhu ruang. Memindahkan supernatan dan menambahkan Chloroform. Sentrifugasi $12.000 \mathrm{rpm}$ selama 10 menit pada suhu ruang. Memindahkan supernatan, menambahkan Isopropanol dan $\mathrm{NaAc}$ dan inkubasi selama 1 jam pada suhu $-20{ }^{\circ} \mathrm{C}$, sentrifugasi 12.000 rpm selama 10 menit pada $4{ }^{\circ} \mathrm{C}$. Purifikasi DNA dengan Etanol PA $70 \%$. Menambahkan Buffer TE pada pellet. Menambahkan RNAse, Inkubasi $37^{\circ} \mathrm{C}$ selama $1 \mathrm{jam}$. Menyimpan DNA pada suhu $-20^{\circ} \mathrm{C}$. 


\section{RAPD-PCR}

RAPD-PCR menggunakan formulasi sebagai berikut DNAtemplate, MasterMix, Primer OPB-07 (GGT-GAC-GCA-G), dan $\mathrm{ddH}_{2} \mathrm{O}$. Program PCR yang digunakan yaitu pre-denaturasi : $95^{\circ} \mathrm{C}$ selama 3 menit, denaturasi : $95^{\circ} \mathrm{C}$ selama 15 detik, annealing :32 ${ }^{\circ} \mathrm{C}$ selama 30 detik, extension : $72{ }^{\circ} \mathrm{C}$ selama 20 detik, dan postextension : $72{ }^{\circ} \mathrm{C}$ selama 5 menit dengan 40 siklus. Hasil PCR dielektroforesis dengan 75 volt selama 40 menit pada gel agarose $2 \%$. Gel agarose divisualisasikan dibawah cahaya UV.

\section{HASIL DAN PEMBAHASAN}

Pemuliaan tanaman merupakan suatu kegiatan mengubah susunan genetik individu maupun populasi tanaman untuk suatu tujuan diperoleh tanaman yang lebih bermanfaat. Informasi mengenai karakter morfologi sangat diperlukan untuk menentukan kekerabatan antar varietas yang digunakan sebagai dasar penentuan tetua dalam pemuliaan tanaman. Hasil penelitian membahas mengenai karakteristik morfologi dengan menggunakan paramater yang meliputi tinggi tanaman $(\mathrm{cm})$, jumlah anakan produktif, umur panen (HSS), bobot 100 biji (gram), bentuk gabah, warna gabah dan warna beras serta pola pita DNA.

Tabel 1. Data Morfologi 21 Varietas Padi Aromatik

\begin{tabular}{|c|c|c|c|c|c|c|}
\hline No & Varietas & $\begin{array}{l}\text { Tinggi Tanaman } \\
(\mathrm{cm})\end{array}$ & $\begin{array}{c}\text { Jumlah Anakan } \\
\text { Produktif }\end{array}$ & $\begin{array}{c}\text { Umur Berbunga } \\
\text { (HSS) }\end{array}$ & $\begin{array}{c}\text { Umur Panen } \\
\text { (HSS) }\end{array}$ & $\begin{array}{c}\text { Bobot } 100 \text { Gabah } \\
\text { (gram) }\end{array}$ \\
\hline 1 & Rojolele Delanggu & 119,00 & 6 & 143 & 174 & 1,82 \\
\hline 2 & MW Banjarnegara & 74,77 & 10 & 91 & 118 & 2,63 \\
\hline 3 & Pare Pulu Mandoti & 143,67 & 2 & 138 & 174 & 2,78 \\
\hline 4 & Situ Bagendit & 61,33 & 4 & 88 & 116 & 2,11 \\
\hline 5 & Radah Putih & 99,60 & 7 & 105 & 126 & 2,37 \\
\hline 6 & Mentik Susu & 73,33 & 6 & 105 & 130 & 1,52 \\
\hline 7 & Sintanur & 93,50 & 17 & 92 & 124 & 2,04 \\
\hline 8 & Celebes & 83,40 & 16 & 88 & 118 & 1,65 \\
\hline 9 & Gilirang & 92,37 & 12 & 103 & 123 & 1,86 \\
\hline 10 & Pendok & 160,57 & 6 & 100 & 120 & 2,87 \\
\hline 11 & Situ Patenggang & 79,07 & 12 & 91 & 123 & 2,06 \\
\hline 12 & Mapan 05 & 108,33 & 13 & 97 & 123 & 2,07 \\
\hline 13 & Mentik Wangi & 87,67 & 12 & 99 & 121 & 1,85 \\
\hline 14 & Pandan Wangi & 107,00 & 3 & 143 & 173 & 3,04 \\
\hline 15 & Kurik Kusut & 71,07 & 7 & 111 & 127 & 2,21 \\
\hline 16 & Inpari 7 & 75,83 & 15 & 92 & 125 & 2,10 \\
\hline 17 & Inpari 23 & 108,60 & 4 & 93 & 120 & 2,18 \\
\hline 18 & Batang Gadis & 75,17 & 8 & 92 & 120 & 1,43 \\
\hline 19 & Umbuk Wangi & 104,13 & 8 & 102 & 130 & 2,01 \\
\hline 20 & Genjah Arum & 136,33 & 8 & 105 & 135 & 2,88 \\
\hline 21 & Gogo Fatuk Masin & 98,63 & 1 & 96 & 111 & 1,79 \\
\hline
\end{tabular}

\section{Tinggi Tanaman}

Tinggi tanaman menentukkan postur tanaman padi aromatik. Menurut IRRI (2002), postur tanaman berdasarkan tinggi tanaman dapat diklasifikasikan menjadi tanaman pendek $(<90 \mathrm{~cm})$, sedang $(90-125 \mathrm{~cm})$, dan tinggi $(>125 \mathrm{~cm})$. Hasil pengamatan menunjukkan nilai terendah ditunjukkan pada varietas Situ Bagendit (V4) dengan rerata tinggi yaitu $74,77 \mathrm{~cm}$ dan nilai tertinggi ditunjukkan pada varietas Pendok (V10) dengan rerata tinggi tanaman yaitu 160,57 $\mathrm{cm}$. Menurut Suastika, dkk (2014), tinggi tanaman merupakan salah satu kriteria seleksi tanaman padi, namun postur padi yang tinggi belum tentu menjamin tingkat produksinya.

Nuryanto (2018) menjelaskan postur padi mempengaruhi tingkat keparahan penyakit. Varietas padi dengan postur tinggi dan anakan sedikit umumnya memiliki tingkat keparahan ringan terhadap penyakit hawar pelepah daun (Rhizoctonia solani) karena cenderung dapat mengurangi suhu dan kelembaban lingkungan di bawah kanopi tanaman. Postur tanaman yang tinggi memudahkan terjadinya kerebahan, yang menyebabkan penghambatan unsur hara, mineral, fotosintat sebagai akibat rusaknya pembuluh xylem dan floem, sehingga diperlukan pemilihan postur tanaman padi yang tepat untuk perakitan padi aromatik.

\section{Jumlah Anakan Produktif}

Pengamatan anakan produktif bertujuan untuk mengetahui potensi suatu varietas dalam kemampuannya berproduktif yaitu dengan menghitung total anakan yang menghasilkan malai bernas. Bedasarkan tabel diatas, nilai rerata tertinggi ditunjukkan pada varietas Sintanur (V7) dan nilai rerata terrendah ditunjukkan pada varietas Gogo Fatuk Masin (V21). Wibowo (2010) menjelaskan bahwa semakin tinggi tanaman cenderung memiliki jumlah anakan yang relatif lebih sedikit serta sebaliknya. Hal ini selaras dengan hasil dibawah, pada varietas Pare Pulu Mandoti (V3) yang memiliki tinggi 143,67 cm memiliki nilai rerata jumlah anakan yang rendah yaitu 2,00 anakan. Tanaman yang pendek yang memiliki jumlah anakan yang banyak diprediksi dapat menghasilkan produksi gabah lebih maksimal karena fotosintat yang dihasilkan lebih tinggi, proses metabolisme lebih dimaksimalkan untuk pembentukan malai dibandingkan dengan penambahan tinggi.

\section{Umur Berbunga dan Panen}

Perhitungan umur berbunga dilakukan untuk mengetahui lama pengisian gabah hingga masak penuh. Supriyanti, dkk (2015) mengatakan umumnya padi dapat dipanen kurang lebih 35 hari setelah berbunga. Variabel umur panen merupakan aspek yang perlu sangat diperhatikan karena umur panen merupakan komponen untuk menghitung produktivitas padi. Simarmata (2010) menjelaskan umur panen dapat dijadikan penentu dalam perhitungan intensitas panen dalam satu tahun. Intensitas panen yang baik untuk petani yaitu berkisar $200-300 \%$ atau dua sampai tiga kali panen dalam satu tahun. Umur panen padi dapat diklasfisikasikan menjadi umur ultra genjah $(<90$ HSS), sangat genjah (90-104 HSS), genjah (105-124 HSS), sedang (125-150 HSS) dan dalam (>151 HSS) (BB Padi, 2009).

\section{Bobot 100 Gabah}

Berdasarkan grafik dibawah, setiap varietas memiliki bobot 100 biji yang sangat bervariasi dengan nilai rerata 1,43-3,04 gram. Nilai terendah ditunjukkan oleh varietas Batang Gadis (V18) dengan berat 1,43 gram, dan nilai rerata tertinggi ditunjukkan oleh varietas Pandan Wangi (V14) dengan rerata nilai 3,04 gram. Nilai bobot 100 butir gabah berhubungan dengan tinggi tanaman dan umur tanaman. Postur padi yang tinggi cenderung menunjukkan umur tanaman 
yang semakin lama, sehingga periode pengisian bulirnya juga semakin lama yang kemudian membuat bobot gabahnya semakin berat. Postur tanaman yang tinggi menandakan semakin banyak fotosintat yang dihasilkan sehingga akan mempengaruhi bobot gabah karena mempunyai malai yang panjang dan gabah bernas yang lebih banyak (Rohaeni dan Permadi, 2012).

\section{Bentuk dan Warna Gabah}

Berdasarkan gambar berikut, terdapat 2 bentuk gabah yang dihasilkan dari 21 varietas padi aromatik yaitu ramping dan sedang. Varietas yang memiliki gabah berbentuk sedang diantaranya Mentik Wangi Banjarnegara (V2), Pare Pulu Mandoti (V3), Sintanur (V7), Pendok (V10), Situ Patenggang (V11), Mentik Wangi (V13), Pandan Wangi (V14), Umbuk Wangi (V19), dan Genjah Arum (V20) dan lainnya tergolong dalam bentuk gabah ramping. Limbongan dan Djufry (2015) menjelaskan adanya ekor pada gabah merupakan salah satu ciri karakter padi unggul lokal. Karakteristik warna gabah merupakan variabel pengamatan kualitatif yang memberikan ciri khas setiap varietas atau kultivarnya. Perbedaan warna gabah pada beras dipengaruhi berbagai faktor, salah satunya kadar antosianin yang terkandung didalamnya.

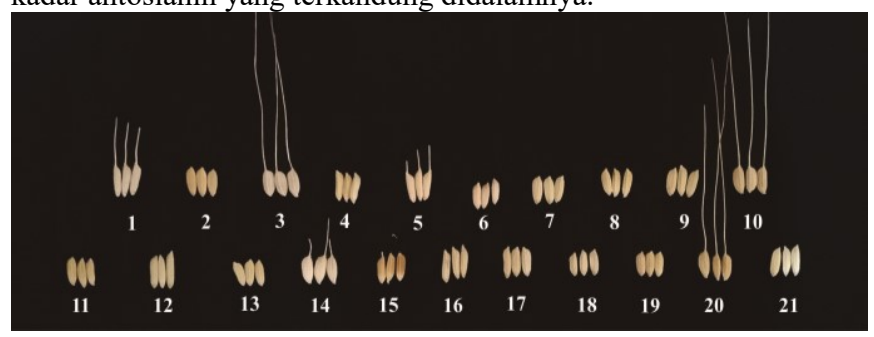

Gambar 1. Warna Gabah 21 Varietas Padi Aromatik.

\section{Warna Beras}

Warna beras juga merupakan karakteristik kualitatif yang dibutuhkan dalam penentuan kekerabatan tanaman. Klasifikasi beberapa jenis beras berdasarkan warnanya, yaitu beras putih, merah dan hitam. Suliartini, dkk (2011) menjelaskan warna merah pada beras terbentuk dari pigmen antosisanin yang terkandung pada perikarp, tegmen dan gabah. Antosianin merupakan pigmen larut air yang secara alami terdapat pada berbagau jenis tumbuhan. Pigmen antosianin pada beras diidentifikasi oleh gen yang bersifat unggul. Beras merah yang memiliki kadar antosianin yang tinggi umunta memiliki warna beras yang lebih gelap sedangkan beras yang memiliki antosianin yang lebih sedikit memiliki warna yang lebih cerah. Perbedaan warna beras dapat dijadikan acuan untuk menduga kandungan antosianin pada beras.

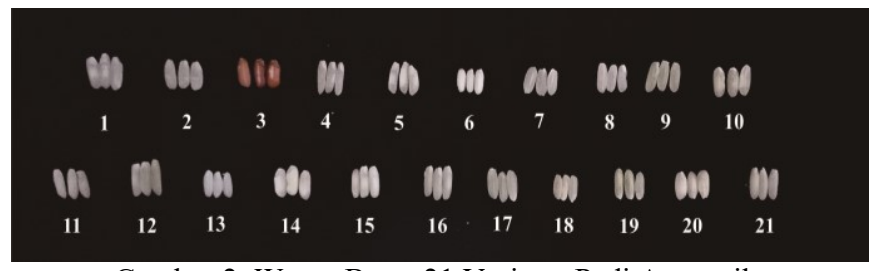

Gambar 2. Warna Beras 21 Varietas Padi Aromatik.

\section{Analisis Kekerabatan}

Dendrogram diatas menujukkan terdapat 2 cluster dan 4 subcluster yang terbentuk. Penggelompokkan setiap cluster/kelompok pada dendrogram didasarkan pada kesamaan atau kemiripan yang ada pada setiap varietas. Cluster I yang diduduki oleh varietas Rojolele Delanggi (V1), Pandan Wangi (V14), Pare Pulu Mandoti (V3) dan Genjah Arum (V21) cenderung memiliki kesamaan pada variabel tinggi tanaman, umur berbunga, umur panen. Selanjutnya berkaitan dengan variabel umur panen juga mempengaruhi kemiripan anatara varietas Rojolele Delanggu (V1) dan Pandan Wangi (V14). Persamaan yang paling mencolok yaitu pada tipe gabah yang berekor sedang. Sedangkan varietas Genjah Arum (V20) dan Pare Pulu Mandoti (V3) yang berada dalam satu cluster memiliki gabah berekor panjang.

Secara umum, cluster II terdiri dari beberapa varietas yang memiliki kemiripan pada variabel tinggi tanaman yang rendah, jumlah anakan banyak, umur genjah, bobot 100 biji berkisar 1,432,63 gram, dan warna beras putih. Pembagian setiap kelompok merupakan penggelompokkan berdasarkan nilai kemirapan yang lebih spesifik. Cluster II sub-cluster II terdiri dari Mentik Susu (V6), Kurik Kusut (V15) dan Umbuk Wangi (V19). Kemiripan yang paling terlihat yaitu pada variabel umur berbunga dan panen yang sama. Mentik Susu (V6) dan Umbuk Wangi (V19) berbunga pada umur 84HST dan panen pada umur 109 HST, sedangkan Kurik Kusut berbungan pada 90 HST dan panen pada umur 105,67 HST dimana nilainya di jauh dibandingkan keduanya.

Cluster II sub-cluster II terbagi menjadi 4 grup. Secara keseluruhan dari beberapa variabel yang diamati ini memiliki kemiripan pada variabel pengamatan. Misalnya pada grup 3 yang terdiri dari varietas Radah Putih (V5), Inpari 23 (V17), dan Gogo Fatuk Masin (V21). Grup 3 dikelompokkan berdasarkan jumlah anakan produktif yang sangat sedikit dibandingkan varietas-varietas. Grup 3 terdiri dari Situ Bagendit (V4) dan Inpari 7 (V16). Variabel yang memiliki kemiripan antar kedua varietas ditunjukkan pada bobot 100 biji. Varietas yang berada pada grup 4 sedikit terdapat perbedaan. Varietas Pendok (V10) berkedudukan pada sub-grup berbeda. Faktor yang mempengaruhi yaitu adanya ekor pada ujung gabah serta memiliki postur yang lebih tinggi dibandingkan varietas lainnya.

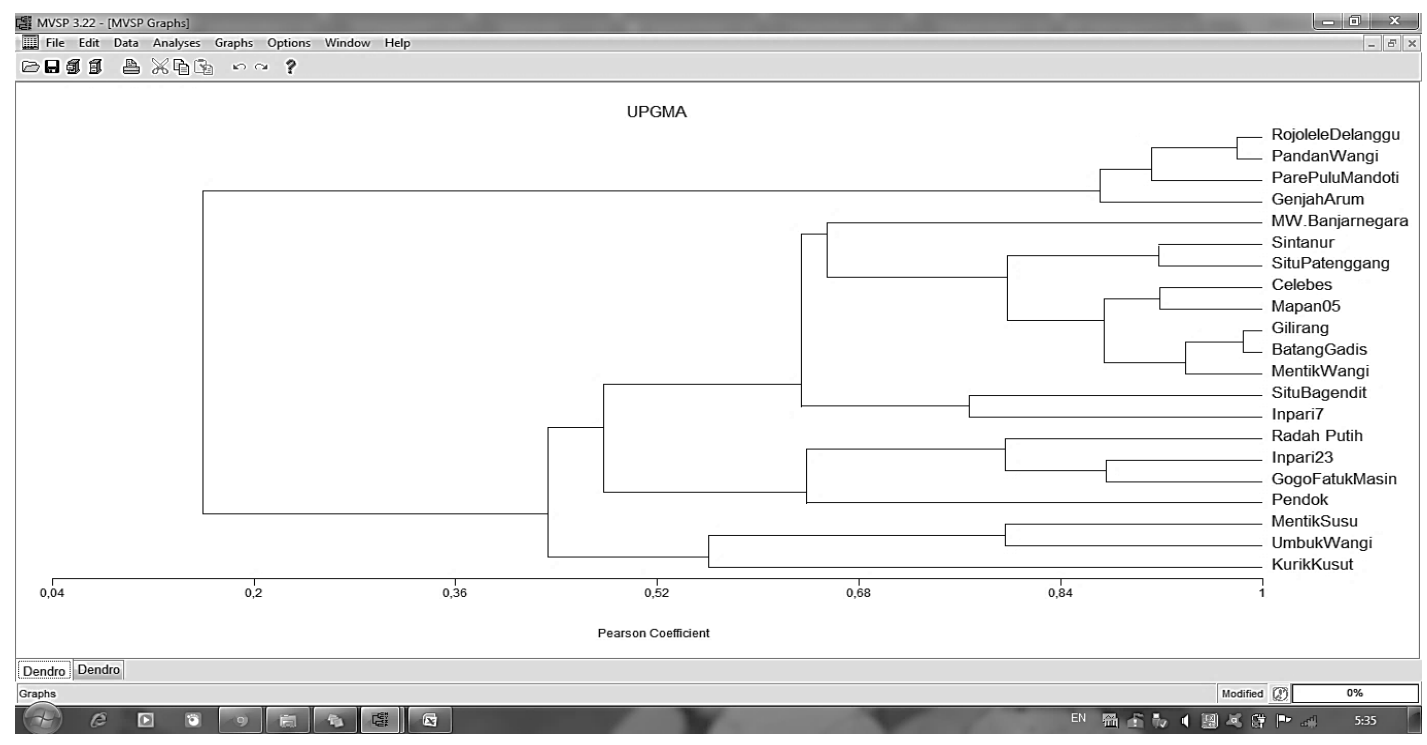

Gambar 3. Dendrogram Fenotipe 21 Varietas Padi Aromatik menggunakan UPGMA dengan DIST Coefficient. 


\section{Identifikasi Molekuler}

Penanda RAPD merupakan metode untuk mengidentifikasi jumlah polimorfisme pada genom dengan cepat dan efisien sehingga cocok untuk studi keanekragaman genetik, hubungan kekerabatan, peta genetik, dan sidik jari DNA. Amplifikasi DNA dibedakan menjadi pola pita DNA polimorfik dan monomorfik. Persamaan pada amplifikasi DNA menujukkan kekerabatan yang lebih dekat. Hasil identifikasi morfologi dan molekuler umumnya tidak bisa sama namun dapat dibandingkan untuk mendapatkan hasil yang lebih akurat dalam analasis kekerabatan.

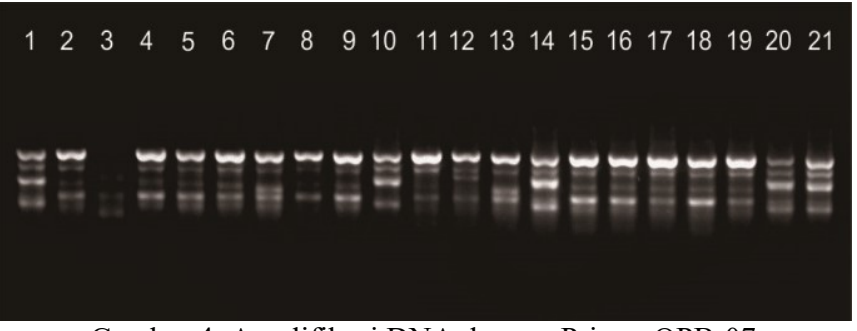

Gambar 4. Amplifikasi DNA dengan Primer OPB-07.

Berdasarkan gambar diatas dibandingkan dengan dendrogram fenotipe, terdapat beberapa persamaan pada penggelompokan, misalnya varietas Rojolele Delanggu (V1) dengan Genjah Arum (V20) yang menduduki cluster I, varietas Mentik Wangi Banjarnegara (V3) dengan Gilirang (V9) yang menduduki cluster II sub-cluster II pada kelompok 1 dan Celebes (V8) dengan Situ Patenggang (V11) pada kelompok yang sama. Hal ini dapat dikatakan terdapat persamaan antara fenotipe dengan genotipe tanaman.

\section{KESIMPULAN}

1. Karakteristik morfologi 21 varietas padi aromatik menunjukkan hasil yang berbeda nyata terhadap varibael tinggi tanaman, jumlah anakan produktif, umur berbunga, umur panen, bobot 100 biji, bentuk gabah, warna gabah, dan warna beras.

2. Dendrogram fenotipe menghasilkan 2 Cluster 2 sub-cluster 4 grup.

3. Amplifikasi DNA menujukkan adanya persamaan antara fenotipe dan genotipe tanaman.

\section{DAFTAR PUSTAKA}

Balai Besar Penelitian Tanaman Padi. 2009. Klasifikasi Umur Padi http://bbpadi.litbang.pertanian.go.id/index.php diakses pada 24 September 2018.

Elsera, T., Jumali, dan B, Kusbiantoro.2014.Karakteristik Flavor Beras Varietas Padi Aromatik dari Ketinggian Lokasi yang Berbeda. Pertanian Pangan, 33(1): 27-35.

Giraud, G.2013. The World Market of Fragrant Rice, Main Issues and Perspectives.International Food and Agribusiness Management Review, 16(2): 1-20

Haryanto, T.A.D.2005.Perbedaan Kandungan 2,acetyl-1-pyrrolin dan Hasil Biji Empat Kultivar Padi Pada Dua Lokasi Tanam. Pembangunan Pedesaan, 5(1): 50-53.

IRRI.2002.Standar Evaluation System for Rice (SES).Philipies:International Rice Reseach Intitute.

Limbongan, Y dan F. Djufry.2015.Karakteristik dan Observasi Lima Aksesi Padi Lokal Dataran Tinggi Toraja, Sulawesi Selatan.Plasma Nutfah, 21(2): 61-70.
Nugroho, K., Slamet, dan P. Lestari.2017. Keragaman Genetik 24 Varietas Padi Sawah dan Padi Gogo (Oryza sativa L.) Indonesia Berdasarkan Marka SSR.Scripta Biologica, 4(1): 510 .

Nuryanto, B.2018.Pengendalian Penyakit Tanaman Padi Berwawasan Lingkungan Melalui Pengelolaan Komponen Epidemik.Litbang Pertanian, 37(1): 1-12.

Rochambeau, H., F.Fournet-Hanocq., and J.Vu Tien Kang.2000. Measuring and Managing Genetic Variability in Small Populations.Annales de Zootechnie, 49(1): 77-93.

Rohaeni, W.R dan K. Permadi.2012.Analisis Sidik Lintas Beberapa Karakter Komponen Hasil terhadap Daya Hasil Sawah pada Aplikasi Agrisimba.Agrotrop, 2(2):185-190.

Saidah., I.K. Suwitra, Sakka Samudin, dan Syafruddin.2015. Sifat Morfologi Padi Lokal Kamba di Sulawesi Tengah. Biodiv Indon, 1(3): 548-553.

Simarmata.M.2010.Deskripsi Morfologi Kultivar Padi Gogo di Bengkulu.Akta Agrosia, 13(1): 8-15.

Suastika, I.B.K., A.A.N.B. Kamandulu dan S.A.N. Aryawati.2014.Karakter Agronomi dan Ketahanan Beberapa Varietas Unggul Baru Padi terhadap Hawar Daun Bakteri.Pros Seminar Nasional, 1(1): 143-153.

Suliartini, N.W.S., G.R. Sadimantara, T. Wijiyanto, dan Muhidin.2011.Pengujian Kadar Antosianin Padi Gogo Beras Merah Hasil Koleksi Plasma Nutfah Sulawesi Tenggara.Crop Agro, 4(2): 43-48.

Tenda, E., M. Tulalo, dan Miftahorrachman.2009. Hubungan Kekerabatan Genetik Antar Sembilan Aksesi Kelapa Asal Provinsi Sulawesi Utara.Littri, 15(3): 139-144.

Wahid dan M. Nurdin.2013.Kajian Adaptasi Beberapa Varietas Unggul Baru Padi Sawah di Kabupaten Seram Bagian Timur.Widyariset, 16(3): 451-456.

Wibowo, P.2010.Pertumbuhan dan Produktivitas Galur Harapan Padi (Oryza sativa L.) Hibrida di Desa Ketaon Kecamatan Banyudono Boyolali.Skripsi.Surakarta: Universitas Sebelas Maret. 